\title{
ВІДТВОРЮВАЛЬН ЯКОСТІ СВИНОМАТОК ІРЛАНДСЬКОГО ПОХОДЖЕННЯ ЗА ЧИСТОПОРОДНОГО РОЗВЕДЕННЯ ТА СХРЕЩУВАННЯ В УМОВАХ ПРОМИСЛОВОГО КОМПЛЕКСУ
}

\author{
Оглобля Вікторія Вікторівна \\ здобувач ступеня вищої освіти «Доктор філософії» \\ Полтавська ержавна аграрна академія \\ ORCID: 0000-0002-4630-7222 \\ E-mail: vika.ohloblia@gmail.com
}

Повод Микола Григорович доктор сільськогосподарських наук, профресор Сумський національний аграрний університет ORCID: 0000-0001-9272-9672 E-mail: nic.pov@ukr.net

Вивчались показники відтворної продуктивності свиноматок порід великої білої та ландрас в умовах промислового комплексу центрального степу України за чистопородного розведення та реципрокного схрещування. Встановлено, що різнииі за багатоплідністю у свиноматок першої, другої та третьої груп не виявлено, тоді як в помісних гніздах свиноматок третьої групи виявилось вірогідно $(p<0,01)$ на 1,1 голови більше живих поросят при народжені. Водночас в чистопородних гніздах свиноматок великої білої породи виявилась найбільша кількість мертвонароджених поросят 12,41\%, що вірогідно вище в порівнянні з аналогами породи ландрас як за чистопородного розведення, так і схрещування (p<0,01-0,001). За великоплідністю суттєвих розбіжностей між тваринами піддослідних груп не спостерігалось. Відмінностей за збереженістю поросят в чистопородних гніздах тварин великої білої та ландрас порід не виявлено, тоді як за схрещування маток цих порід встановлена вірогідна перевага тварин породи ландрас над великими білими аналогами на $7,5 \%(p<0,05)$. Кількість поросят при відлучені в чистопородних гніздах свиноматок порід великої білої та ландрас була вірогідно на 0,7...0,9 голови менше порівняно з помісними гніздами свиноматок породи ландрас, осіменених спермою кнурів великої білої породи $(p<0,001)$ та на 0,2...0,4 голови в порівнянні з помісними гніздами свиноматок за реципрокного схрещування $(p \leq 0,05)$. В цілому за обох варіантів схрещування виявлена тенденція до збільшення кількості поросят при відлучені порівняно з чистопородним розведенням батьківських форм.

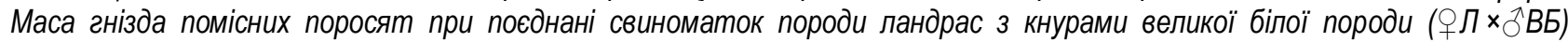
виявилася вірогідно $(p<0,05)$ на 5,0...5,3 ка вищою порівняно з гніздами чистопородних тварин. Водночас помісні тварини від зворотного схрещування маток великої білої породи з кнурами породи ландрас мали тенденцію до перевищення за цією ознакою чистопородних ровесників на 2,1-2,4 ке та поступалися за нею своїм аналогам при поєднані свиноматок породи ландрас з кнурами великої білої породи на 2,9 ке.

Ключові слова: свиноматка, порода, схрещування, приріст, багатоплідність, збереженість, маса гнізда,

DOI: https://doi.org/10.32845/bsnau.Ivst.2020.1.15

На сучасному етапі розвитку суспільства однією 3 умов успішного виробництва $€$ його інтенсифікація і індустріалізація. Ці процеси змушують виробників свинини до впровадження потокового, промислового виробництва, з використанням найсучасніших способів годівлі, умов утримання та методів розведення свиней $[5,10]$.

Невід'ємною складовою процесу виробництва свинини $€$ інтенсивні методи відтворення тварин. В сучасному свинарстві для цього використовуються як вітчизняні, так і зарубіжні генотипи свиней $[1,2,6,12,15]$ Але при використанні свиней будь-якого походження виробники впроваджують такі форми їх розведення, які б максимально використовували біологічні особливості тваринного організму $[7,13]$. В сучасному свинарстві для використання ефекту гетерозису використовується промислове схрещування та гібридизація. Гібридизація за визначенням G.H Shull [20] - $є$ вищим рівнем промислового схрещування за участі спеціально відселекціонованих материнських і батьківських форм, з стійкою передачею потомству відтворювальних, відгодівельних та забійних якостей. Як зауважують И. Горин., И.Никитченко [7,] сучасне розуміння терміну внутрішньо-видової гібридизації - це

поєднання відселекціонованих за окремими ознаками батьківських і материнських генотипів для отримання високопродуктивних товарних гібридів. За повідомленнями $[1,2,4,8,9,10,12,13]$ за рахунок гібридизації досягається суттєве, на 5-22 \%, збільшення продуктивності свиней та поліпшення якості продукції. У свинарстві за словами А. Phelps [19], гібридами прийнято називати нащадків одержаних від поєднання кнурів і свиноматок спеціально відселекціонованих порід, типів і ліній як чистопородних, так і синтетичних, які перевірені на комбінаційну здатність. Розробці програм гібридизації та вивченню її ефрективності присвячено велику кількість робіт вітчизняних та зарубіжних вчених $[1,2,4,8,9,10,12,13,15$, $16,17,18]$. Але цей процес досить динамічний і вимагає постійного вдосконалення [6], особливо з врахуванням глобалізації ринку генетичного матеріалу у свинарстві. Як стверджують А. Гетя [6], Н. Піотрович [10], В. Топіха із співавторами [11], А. Федяєва [13], в Україну останнім часом завозиться велика кількість свиней зарубіжного походження, без врахування їх адаптаційної здатності до нових геокліматичних умов використання. В зв'язку з чим метою статті $€$ дослідження актуального питання підвищення продуктивності свиней зарубіжного походження в умовах 
промислових комплексів степової зони України

Матеріал та методи досліджень. Для проведення досліджень залежності відтворювальних якостей свиноматок за різних методів розведення було за принципом груп аналогів відібрано чотири групи свиноматок по 60 голів в кожній. Першу та третю групи склали чистопородні свиноматки великої білої породи ірландського походження генетичної компанії Хермітаж Генетікс. До другої та четвертої групи ввійшли чистопородні їх аналоги породи ландрас ірландського походження тієї ж компанії. Свиноматок I групи, які були контролем, осіменяли спермою кнурів великої білої породи ірландської селекції. Спермою цих же кнурів осіменяли і тварин IV (дослідної) групи. Свиноматок II та III (дослідних) груп осіменяли спермою кнурів породи ландрас ірландської селекції. Утримання свиноматок всіх чотирьох груп було ідентичним в усі періоди репродуктивного циклу. Годівля також була ідентичною, повнораціонними збалансованими комбікормами власного виробництва. Після постановки на опорос враховували наступні показники продуктивності: загальну кількість народжених поросят, багатоплідність, масу гнізда поросят при народженні, кількість, індивідуальну масу та масу гнізда поросят при відлучені.

Комплексну оцінку відтворних якостей свиноматок визначали за допомогою оціночного індексу відтворювальних якостей, розробленого Лашем та Мольна у модифікації М.Д. Березовського та Д.В. Ломако [3]:

$$
I=B+2 W+35 G
$$

де В-кількість поросят при народженні, гол;

W - кількість відлучених поросят, гол.;

$\mathrm{G}$ - середньодобовий приріст поросят до відлучення, кг. Селекційний індекс відтворювальних якостей свиноматок (СІВЯС) визначали згідно методики О.М. Церенюка [14]:

$$
\text { CIBЯC }=6 \mathrm{X}_{1}+9,34\left(\frac{\mathrm{X}_{2}}{\mathrm{X}_{3}}\right)
$$

де СІВЯС - селекційний індекс відтворювальних якостей свиноматок

$\mathrm{X}_{1}$ - багатоплідність, гол;

$\mathrm{X}_{2}$ - маса гнізда при відлученні, кг;

$\mathrm{X}_{3}$ - термін відлучення, діб;

6 та 9,34 - коефіцієнти.

Результати дослідження. Отримані показники, що наведені в таблиці 1 свідчать, що найбільшою потенціальною багатоплідністю відрізнялись свиноматки великої білої породи, як при чистопородному розведенні, так і при схрещуванні. Вони народжували вірогідно більше на 1,2...1,4 поросят порівняно з тваринами породи ландрас, за їх чистопородного розведення $(p<0,01)$ та на $0,4 \ldots 0,6$ за схрещування 3 кнурами великої білої породи. Водночас в чистопородних гніздах свиноматок великої білої породи виявилась найбільша кількість мертвонароджених поросят $12,41 \%$, що вірогідно вище в порівнянні з аналогами породи ландрас як за чистопородного розведення, так і схрещування ( $<<0,01-0,001)$. Також тварини цієї групи мали вірогідно вищу кількість мертвонароджених поросят в порівнянні 3 свиноматками великої білої породи за схрещування їх 3 кнурами породи ландрас. Цей факт спричинив відсутність вірогідної різниці за багатоплідністю у свиноматок першої, другої та третьої груп, тоді як в помісних гніздах свиноматок третьої групи виявилось вірогідно ( $p<$ 0,01) на 1,1 голови більше живих поросят при народжені.

За великоплідністю суттєвих розбіжностей між тваринами піддослідних груп не спостерігалось.

Збереженість поросят в чистопородних гніздах першої та другої групи практично не виявлено, тоді як за схрещування маток цих порід встановлена вірогідна перевага тварин породи ландрас над великими білими аналогами на $7,5 \%(p<0,05)$, що, на наш погляд, спричинено суттєво більшою у свиноматок третьої групи багатоплідністю.

\begin{tabular}{|c|c|c|c|c|}
\hline Група свиноматок & $\begin{array}{c}\text { І група } \\
\text { (контрольна) } \\
(\text { ВБ } \times \precsim \text { ВБ) } \\
\text { n=60 }\end{array}$ & 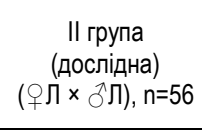 & $\begin{array}{c}\text { III група } \\
\text { (дослідна) } \\
\text { (фВБ } \times \text { §Л }) \\
\text { n=59 } \\
\end{array}$ & 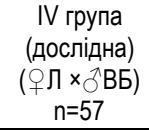 \\
\hline Всього народжених поросят, гол. & $17,0 \pm 0,28$ & $15,8 \pm 0,27^{* *}$ & $17,2 \pm 0,35$ & $16,6 \pm 032$ \\
\hline Багатоплідність, гол. & $14,7 \pm 0,25$ & $14,5 \pm 0,24$ & $15,8 \pm 0,34^{* *}$ & $15,0 \pm 0,31$ \\
\hline Кількість мертвонароджених поросят, гол. & $2,26 \pm 0,18$ & $1,33 \pm 0,12^{* * *}$ & $1,29 \pm 0,14^{* * *}$ & $1,55 \pm 0,19$ \\
\hline Частка мертвонароджених поросят, \% & $12,4 \pm 0,93$ & $7,7 \pm 0,67^{\star \star *}$ & $7,32 \pm 0,81^{* * *}$ & $8,50 \pm 0,96^{* *}$ \\
\hline Великоплідність, кг & $1,31 \pm 0,007$ & $1,32 \pm 0,007$ & $1,29 \pm 0,008$ & $1,32 \pm 0,006$ \\
\hline Маса гнізда поросят при народженні, кг & $19,3 \pm 0,38$ & $19,1 \pm 0,36$ & $20,4 \pm 0,49$ & $19,8 \pm 0,45$ \\
\hline Збереженість, \% & $82,3 \pm 1,63$ & $82,1 \pm 1,96$ & $77,8 \pm 1,85$ & $85,3 \pm 2,76$ \\
\hline Кількість поросят при відлучені, гол. & $12,1 \pm 0,09$ & $11,9 \pm 0,12$ & $12,3 \pm 0,15$ & $12,8 \pm 0,12^{* * *}$ \\
\hline Маса одного поросяти при відлучені, кг & $6,66 \pm 0,079$ & $6,75 \pm 0,066$ & $6,72 \pm 0,118$ & $6,69 \pm 0,143$ \\
\hline Маса гнізда поросят при відлучені, кг & $80,6 \pm 1,65$ & $80,3 \pm 1,32$ & $82,7 \pm 1,9$ & $85,6 \pm 1,71^{*}$ \\
\hline Середньодобовий приріст поросят сисунів, г & $198 \pm 3,2$ & $201 \pm 3,3$ & $201 \pm 4,7$ & $199 \pm 3,9$ \\
\hline CІВЯС, балів & 115,1 & 113,8 & 123,9 & 116,8 \\
\hline Оціночний індекс, балів & 45,8 & 45,3 & 47,4 & 47,6 \\
\hline
\end{tabular}

Відтворювальні якості свиноматок за різного варіанту розведення, $\mathrm{M \pm m}$

Різна кількість живих поросят при народжені та їх збереженість під час підсисного періоду спричинили різницю в кількості поросят при відлучені. В чистопородних гніздах свиноматок першої та другої груп їх було вірогідно на $0,7 \ldots 0,9$ голови менше порівняно 3 помісними гніздами свиноматок четвертої групи ( $<<0,001)$ та на $0,2 \ldots 0,4$ голови в порівнянні з помісними гніздами свиноматок третьої групи (p $\leq 0,05)$. Водночас кількість поросят при відлученні в помісних гніздах четвертої групи була на 0,5 поросяти вищою порівняно з реципрокним варіантом схрещування (III група) ( $p<0,05)$. В цілому за обох варіантів схрещування виявлена тенденція до збільшення кількості поросят при 
відлучені порівняно з чистопородним розведенням батьківських форм.

За індивідуальною масою поросят при відлучені вірогідної різниці між тваринами піддослідних груп не встановлено, хоча і спостерігалась тенденція до іії підвищення у чистопородних поросят породи ландрас.

Maca гнізда помісних поросят четвертої групи виявилася вірогідно $(p<0,05)$ на 5,0..5,3 кг вищою порівняно з чистопородними гніздами тварин першої та другої груп. Водночас помісні тварини від зворотного схрещування маток великої білої породи з кнурами породи ландрас мали тенденцію до перевищення за цією ознакою чистопородних ровесників з першої та другої груп на 2,1-2,4 кг та поступалися за нею своїм аналогам з четвертої групи на 2,9 Кг.

За середньодобовими приростами поросят в підсисний період суттєвих розбіжностей між тваринами піддослідних груп не встановлено, і не виявлено чіткої тенденції в розрізі груп.

За комплексним показником відтворних якостей свиноматок розрахованим за методикою М.Б. Березовського кращими виявились свиноматки породи ландрас яких осіменяли спермою кнурів великої білої породи, тоді як селекційний індекс відтворювальних якостей свиноматок виявився найкращим у маток великої білої породи при схрещуванні з кнурами породи ландрас. За обома індексами кращі результати отримані при схрещуванні порівняно 3 чистопородним розведенням.

Висновки. Схрещування свиней порід великої білої та ландрас ірландського походження в умовах промислового комплексу степу України сприяло підвищенню багатоплідності кількості поросят та мас їх гнізда при відлучені.

Не встановлено залежності від методу розведення свиней їх великоплідності, збереженості та індивідуальної маси поросят при відлучені.

Встановлено тенденцію до підвищення маси помісних гнізд поросят при відлучені порівняно 3 чистопородними.

За комплексною оцінкою відтворювальних якостей свиноматок кращі результати отримані при схрещуванні порівняно з чистопородним розведенням.

\section{Список використаної літератури:}

1. Бабань О. А. Схрещування у свинарстві. Свинарство. Корисний блог. 2017. URL: http://pig.tekro.ua/viroshchennya/item/27-shreshhuvannja-u-svinarstvi.html.)

2. Бальников А. А, Гридюшко И. Ф., Гридюшко Е. С. Оценка биологических особенностей свиней различной сочетаемости в условиях промышленной технологии. Свинарство. Міжвід. темат. наук. зб. ІС і АПВ НААН. Полтава, 2019. Вип. 73.С.186 - 191.

3. Березовский Н. Д., Почерняев Ф. К., Коротков В. А. Методика моделирования индексов для использования их в селекции свиней. Методы улучшения процессов селекции, разведения и воспроизводства свиней (методические указания). М., 1986. С. $3-14$.

4. Березовський М. Д., Наріжна О. Л., Вовк В. О. Одержання свинини на гібридній основі в умовах фермерського господарства. Свинарство. Міжвід. темат. наук. зб. ІС і АПВ НААН. Полтава, 2018. Вип. 71. С. 29 - 40.

5. Березовський М. Д., Волощук В. М., Гришина Л. П., Ващенко П. А., Вовк В. О., Волощук О.В. та ін. Програма селекції великої білої породи свиней в Україні на 2018-2025 роки. Полтава, ТОВ «Фірма «Техсервіс», 2018. 111 с.

6. Гетя А. А. Організація селекційного процесу в сучасному свинарстві: монографія. Полтава: Полтавський лimepamop, 2009. $192 \mathrm{c}$. $104-106$.

7. Горин И. Т., Никитченко И. Н. Возможность прогнозирования гетерозиса у свиней. Труды БелНИИЖ. 1969. Т. 10. С.

8. Краснощок О. О. Відтворювальні якості свиноматок за різних методів розведення. Наукове забезпечення інноваційного розвитку агропромислового комплексу в умовах змін клімату: міжнародна науково-практична конференція молодих вчених і спеціалістів, Дніпро, 2017. С. 179.

9. Пелих В. Г., Ушакова С. В., Левченко М. В. Високопродуктивні варіанти поєднань кнурів та свиноматок імпортних м'ясних генотипів. Інтеграція освіти, науки та бізнесу в сучасному середовищі: зимові диспути: тези доп. I міжнародної науково-практичної Інтернет-конфреренції,. Дніпро, 2020. Т.2. С. 539-542.

10. Піотрович Н. А. Формування відтворювальних якостей свиноматок та оцінка їх комбінаційної здатності авторефр. дис. ... канд. с.-г. наук: 06.02 .01 «Розведення та селекція тварин». Миколаїв, 2017. 19 с.

11. Топіха В. С., Лихач В. Я., Лихач А. В. М'ясні якості свиней породи ландрас за різних методів розведення. 36. наук. праць Вінницького НАУ. Серія: Сільськогосподарські науки. 2013. Вип. 5 (78). С. 217-221.

12. Ушакова С. В. Варианты сочетаний хряков и свиноматок мясных генотипов по уровню репродуктивных качеств. $2020 \mathrm{http}: / /$ dspace.ksau. kher-son.ua/ handle/123456789/102 5 (дата звернення 05.01.2020).

13. Федяєва А. С. Обгрунтування ефрективної системи породно-лінійної гібридизації за використання термінальних кнурів: автореф. дис. ... канд. с.-г. наук: 06.02.01. «Розведення та селекція тварин». Харків. 2019. 19 с.

14. Церенюк О. М., Хватов А. І., Стрижак Т. А. Об'єктивна оцінка материнської продуктивності свиней. Таврійський науковий вісник. 2010. Вип. 78, Ч. 2(I). С. 221-227

15. Khramkova О. М. Відтворювальні якості свиноматок за різних поєднань порід і типів. Theoretical and Applied Veterinary Medicine, issue 7(2), 2019 115-119. doi: 10.32819/2019.71021

16. Huang Y. H., Lee Y. P., Yang T. S. and Roan S. W., 2003. Effects of Sire Breed on the Subsequent Reproductive Performances of Landrace Sows. Asian Australasian Journal of Animal Sciences, issue 16 (4), p. 7, DOI: 10.5713/ajas.2003.489. 
17.Kuhlers D. L, Jungst S. B, and Little J. A. 1989. Comparisons of specific crosses from Duroc-Landrace, YorkshireLandrace and Hampshire-Landrace sows managed in two types of gestation systems: pig performance. J Anim Sci., issue 67 (10), pp. 595-602.

18. Knecht D., Srodon S. and Duziński K., 2015. Breed on selected reproductive performance parameters of sows. Arch. Anim. Breed, issue 58, pp. $49-56$.

19. Phelps A. 1976. New hybrid fromesteem Europe. Pig international, Issue 4(6), pp. 10-14.

20. Shull G. H. 1981. Hybridization methods in corn breeding. Amer. Breeding Magazine. issue 1, pp. 98-107.

\section{References:}

1. Baban, O. A. 2017. Skhreshchuvannia u svynarstvi. Svynarstvo [Crossbreeding in pig breeding.]. Korysnyi bloh. URL: http://pig.tekro.ua/viroshchennya/item/27-shreshhuvannja-u-svinarstvi.html.)

2. Balnikov, A. A, Gridyushko, I. F. and Gridyushko, E. S. 2019. Otsenka biologicheskih osobennostey sviney razlichnoy sochetaemosti v usloviyah promyishlennoy tehnologii. [Assessment of biological characteristics of pigs of different compatibility in the conditions of industrial technology]. Svinarstvo. Mlzhvld. temat. nauk. zb. IS I APV NAAN. Poltava, issue 73, pp. 186 - 191.

3. Berezovskiy, N. D., Pochernyaev, F. K. and Korotkov, V. A., 1986. Metodika modelirovaniya indeksov dlya ispolzovaniya in $\mathrm{v}$ selektsii sviney [Methodology for modeling indices for use in breeding pigs]. Metodyi uluchsheniya protsessov selektsii, razvedeniya i vosproizvodstva sviney (metodicheskie ukazaniya), pp. 3-14.

4. Berezovskyi, M. D., Narizhna, O. L. and Vovk, V. O., 2018. Oderzhannia svynyny na hibrydnii osnovi v umovakh fermerskoho hospodarstva [Obtaining pork on a hybrid basis in the conditions of a farm.]. Svynarstvo. Mizhvid. temat. nauk. zb. IS $i$ APV NAAN, issue 71, pp. $29-40$.

5. Berezovskyi, M. D., Voloshchuk, V. M., Hryshyna, L. P., Vashchenko, P. A., Vovk, V. O. and Voloshchuk O. V., 2018. Prohrama selektsii velykoi biloi porody svynei v Ukraini na 2018-2025 roky [Breeding program of a large white breed of pigs in Ukraine for 2018-2025]. Handbook TOV «Firma «Tekhservis», p. 111.

6. Hetia, A. A., 2009. Orhanizatsiia selektsiinoho protsesu v suchasnomu svynarstvi: monohrafiia [Organization of breeding process in modern pig breeding: a monograph]. Poltava: Poltavskyi literator, $192 \mathrm{p}$.

7. Gorin, I. T. and Nikitchenko, I. N., 1969.Vozmozhnost prognozirovaniya geterozisa u sviney [Ability to predict heterosis in pigs]. Trudyi BeINIIZh, issue 10, pp. 104-106.

8. Krasnoshchok, O. O., 2017. Vidtvoriuvalni yakosti svynomatok za riznykh metodiv rozvedennia [Reproductive qualities of sows by different breeding methods]. Naukove zabezpechennia innovatsiinoho rozvytku ahropromyslovoho kompleksu v umovakh zmin klimatu, Tezy dop. mizhnarodnoi naukovo-praktychnoi konferentsii molodykh vchenykh i spetsialistiv, Dnipro, p. 179.

9. Pelykh, V. H., Ushakova, S. V. and Levchenko, M. V., 2020. Vysokoproduktyvni varianty poiednan knuriv ta svynomatok importnykh miasnykh henotypiv [High-yielding combinations of boars and sows of imported meat genotypes]. Intehratsiia osvity, nauky ta biznesu $v$ suchasnomu seredovyshchi: zymovi dysputy, Tezy dop. I mizhnarodnoi naukovo-praktychnoi Internetkonferentsii,. Dnipro, issue 2, pp. $539-542$.

10. Piotrovych, N. A. 2017. Formation of reproductive qualities of sows and evaluation of their combination ability. Abstract of Ph.D. dissertation. Mykolaiv, p. 19.

11. Topikha, V. S., Lykhach, V. la. and Lykhach A. V., 2013. Miasni yakosti svynei porody landras za riznykh metodiv rozvedennia [Meat qualities of Landrace pigs by different breeding methods]. Zb. nauk. prats Vinnytskoho NAU. Seriia: Silskohospodarski nauk, issue 5(78). pp. 217 - 221.

12. Ushakova, S. V., 2020. Variantyi sochetaniy hryakov i svinomatok myasnyih genotipov po urovnyu reproduktivnyih kachestv [Variants of combinations of boars and sows of meat genotypes on the level of reproductive qualities]. URL: http://dspace.ksau. kher-son.ua/ handle/123456789/102 5 (application date 05.01.2020).

13. Fediaieva, A. S., 2019. Substantiation of an effective system of breed-linear hybridization using terminal boars. Abstract of Ph.D. dissertation. Kharkiv, p. 19.

14. Tsereniuk, O. M., Khvatov, A. I. and Stryzhak, T. A., 2010. Obiektyvna otsinka materynskoi produktyvnosti svynei [Objective assessment of maternal productivity of pigs]. Tavriiskyi naukovyi visnyk, issue 78, vol. 2(I). pp. 221 - 227.

15. Khramkova, O. M., 2019. Vidtvoriuvalni yakosti svynomatok za riznykh poiednan porid i typiv [Reproductive qualities of sows in different combinations of breeds and types]. Theoretical and Applied Veterinary Medicine, issue 7(2), pp. 115-119. doi: 10.32819/2019.71021

16. Huang, Y. H., Lee, Y. P., Yang, T. S. and Roan, S. W., 2003. Effects of Sire Breed on the Subsequent Reproductive Performances of Landrace Sows. Asian Australasian Journal of Animal Sciences, issue 16 (4), p. 7, DOI: 10.5713/ajas.2003.489.

17. Kuhlers, D. L, Jungst, S. B, and Little, J. A., 1989. Comparisons of specific crosses from Duroc-Landrace, YorkshireLandrace and Hampshire-Landrace sows managed in two types of gestation systems: pig performance. J Anim Sci., issue 67 (10), pp. 595-602.

18. Knecht, D., Srodon, S. and Duziński, K., 2015. Breed on selected reproductive performance parameters of sows. Arch. Anim. Breed, issue 58, pp. $49-56$.

19. Phelps, A., 1976. New hybrid fromesteem Europe. Pig international, Issue 4(6), pp. 10-14.

20. Shull, G. H., 1981. Hybridization methods in corn breeding. Amer. Breeding Magazine. issue 1, pp. 98-107.

Ogloblia Victoria Viktorivna, Postgraduate, Poltava State Agrarian Academy

Povod Nikolai Grigorovich, Doctor of Agricultural Sciences, Professor, Sumy National Agrarian University 


\section{Reproductive qualities of sowings of Irish origin in purebreed breeding and crossing in an industrial complex}

Studied the indicators of reproductive productivity of great white sows and landrace breeds in the conditions of the industrial complex at the central steppe of Ukraine using purebred breeding and reciprocal crossing. It was found that the differences in fertility in sows of the first, second and third groups were not detected, while in the local nests of sows of the third group was found $(p<0,01)$ 1,1 heads more live piglets at birth. At the same time, the largest number of stillborn piglets of $12,41 \%$ was found in purebred nests of sows of large white breed, which is probably higher in comparison with analogues of landrace breed both in purebred breeding and crossing $(p<0,01-0,001)$. There were no significant differences in the fertility of the animals of the experimental groups. Differences in the safety of piglets in purebred nests of large white and landrace animals were not found, while the crossing of queens of these breeds found a probable advantage of landrace animals over large white counterparts by $7,5 \%(p<0,05)$. The number of piglets weaned in purebred nests of sows of great white and landrace breeds was probably 0,7 $\ldots 0,9$ less compared to local nests of landrace sows inseminated with sperm of large white breed boars $(p<0,001)$ and $0,2 \ldots 0,4$ heads in comparison with local sows' nests by reciprocal crossing $(p \leq 0,05)$. In general, both variants of crossbreeding showed a tendency to increase the number of piglets at weaning compared with purebred breeding of parental forms. The nest weight of local piglets when combined sows of landrace breed with boars of large white breed $\left(O+L^{\wedge} \mathrm{V} V B\right)$ was probably $(p<0,05) 5,0 \ldots 5,3 \mathrm{~kg}$ higher compared to the nests of purebred animals. At the same time, domestic animals from the backcrossing of large white breed queens with landrace boars tended to exceed their purebred peers by 2,1-2,4 $\mathrm{kg}$ and were inferior to their counterparts when combining landrace sows with large white breed boars by $2,9 \mathrm{~kg}$.

Key words: sow, breed, crossbreeding, growth, fertility, preservation, nest weight,

Дата надходження до редакції: 21.01.2020 p. 